\title{
Analisis Jaringan Jalan dengan Metode MKJI 197 pada Kinerja Lalu Lintas di Sekitar Kawasan Perkotaan (Studi Kasus: Perencanaan Tata Guna Lahan Baru di Kawasan Tanrise City Jember)
}

\author{
Marisa Eka Anggraeni 1, Willy Kriswardhana ${ }^{2 *}$, Nunung Nuring Hayati ${ }^{3}$ \\ 1,2 Jurusan Teknik Sipil, Fakultas Teknik, Universitas Jember \\ 3 Program Studi Perencanaan Wilayah Kota, Fakultas Teknik, Universitas Jember \\ *corresponding author, e-mail: willy.teknik@unej.ac.id
}

\begin{abstract}
ABSTRAK
Tanrise City Jember merupakan kawasan superblock yang akan dibangun di Jalan Hayam Wuruk, Kabupaten Jember. Pembangunan meliputi mall, hotel, depo bangunan, ruko, perumahan, dan convention hall. Pembangunan tersebut akan menimbulkan trip production dan trip atraction yang berdampak pada kinerja ruas dan simpang di sekitarnya. Analisis kinerja simpang dan ruas akibat pembangunan Tanrise City Jember perlu dilakukan dengan tujuan untuk mengetahui pengaruhnya pada kondisi eksisting, operasional dan 5 tahun mendatang. Analisis kinerja simpang dan ruas dilakukan dengan menggunakan metode MKJI 1997. Volume kendaraan setiap simpang dan ruas didapatkan dari hasil counting dan faktor pertumbuhan. Penentuan trip production dan trip attraction dengan melakukan survei pada bangunan pembanding. Adapun perkiraan lalu lintas didapatkan dengan menggunakan konsep trip generation, trip distribution, trip assignment. Hasil analisis kinerja simpang Mangli, Transmart dan Argopuro pada kondisi eksisting, operasional dan 5 tahun mendatang menggunakan MKJI 1997 didapatkan kinerja simpang mengalami penurunan. Kinerja simpang terburuk terjadi di Simpang Mangli dengan nilai tundaan (D)>1000 det/smp. Hasil analisis kinerja ruas sekitar pada kondisi eksisiting adalah arus stabil dan kinerja terburuk terjadi di Jl. Brawijaya dengan derajat kejenuhan (DS) $>0,85$ yakni kategori E. Kinerja ruas pada kondisi operasional dan 5 tahun mendatang mengalami penurunan di setiap jam puncaknya.
\end{abstract}

Kata kunci : derajat kejenuhan; MKJI 1997; tundaan

\begin{abstract}
Tanrise City is a superblock area that will be built around Hayam Wuruk street, Jember District. This development will give rises to a new mall, hotel, building depo, shop house, housing, and convention hall. The development will lead to the production trip and attraction trip that will impact the intersections and roads in surrounding areas. Intersections and road performance analysis of Jember Tanrise City development impact need to be studied to understand its effects on the existing condition in the present time and 5 (five) years to come. Intersections and road performance analysis use The 1997 Indonesian Highway Capacity Manual (IHCM). The volume of vehicles for each intersection and roads is obtained from the counting result and the growth factor. Determination of trip production and the trip attraction was by surveying the comparison building. The traffic estimate is obtained using the concept of trip generation, trip distribution, trip assignment. The result of intersections performance of the Mangli Intersections, Transmart Intersections, Argopuro Intersection on the existing condition, in the present time, and 5 (five) years to come to use The 1997 Indonesian Highway Capacity Manual (IHCM) showed that the intersection performance bas decreased. The worst intersection performance occurred at the Mangli intersection with the delay value (D) is $>1000 \mathrm{sec} / \mathrm{pcu}$. The result of road performance in surrounding areas on the existing condition is stable currents, and the worst road performance occurred in Brawijaya street with the Degree Of Saturation (DS) is $>0,85$, which is E category. The road's performance in the present time and 5 (five) years to come has decreased in every peak. hour.
\end{abstract}

Keywords : degree of saturation; delay; MKJI 1997

Cara Mengutip : Anggraeni, M. E., Kriswardhana, W., Hayati, N. N. (2020). Analisis Jaringan Jalan dengan Metode MKJI 197 pada Kinerja Lalu Lintas di Sekitar Kawasan Perkotaan (Studi Kasus: Perencanaan Tata Guna Lahan Baru di Kawasan Tanrise City Jember). Reka Buana : Jurnal Ilmiah Teknik Sipil dan Teknik Kimia, 5(2), 112-124. http://dx.doi.org/10.33366/rekabuana.v5i2.1687 


\section{PENDAHULUAN}

Tanrise City Jember adalah kawasan superblock yang terdiri dari bangunan perumahan, ruko, depo bangunan, hotel, apartemen, convention hall dan mall. Tanrise City Jember dibangun di Jalan Hayam Wuruk, Kec. Kaliwates, Kab. Jember dengan luas lahan 119,260 $\mathrm{m}^{2}$ dan melalui empat tahap pembangunan yang dimulai pada tahun 2019 .

Aktifitas yang terjadi akibat pembangunan Tanrise City Jember dapat menyebabkan pergerakan yang begitu besar sehingga berpengaruh terhadap volume lalu lintas dan kinerja jaringan jalan. Beberapa kinerja lalu lintas yang terpengaruh akibat adanya bangunan baru terjadi pada beroperasinya Bandara Notohadinegoro mengakibatkan adanya pergerakan tarikan perjalanan dan bangkitan perjalanan yang berdampak pada lalu lintas. Kondisi di Simpang MH Thamrin pada tahun 2020 menunjukkan kondisi buruk dengan nilai tundaan terbesar sebesar 171,23 det/smp dan nilai derajat kejenuhan 1,26[1]. Pembangunan Jember Sport Garden mengakibatkan kondisi simpang - simpang di area sekitarnya memiliki kinerja buruk karena nilai tundaan yang tinggi [2]. Nilai tundaan dan DS yang semakin besar sehingga masuk dalam tingkat pelayanan $\mathrm{F}$ menandakan kinerja lalu lintas buruk atau tidak stabil [3] [4] [5] [6].

Berdasarkan beberapa penelitian terdahulu, maka perlu diadakannya analisis untuk mengetahui dampak akibat pembangunan Tanrise City Jember terhadap kinerja lalu lintas disekitarnya. Analisis kinerja lalu lintas dilakukan pada simpang dan ruas jalan saat kondisi eksisting, operasional dan lima tahun mendatang.

Pada penelitian ini, analisis kinerja lalu lintas dilakukan dengan menggunakan metode MKJI 1997. Pemilihan metode ini dikarenakan MKJI 1997 merupakan produk hasil penelitian yang dilakukan secara empiris dibeberapa tempat yang dianggap mewakili kondisi karakteristik lalu lintas di wilayah Indonesia yang dijadikan sebagai manual untuk kegiatan analisis, perencanaan, perancangan dan operasi fasilitas lalu lintas jalan. [7]. Metode MKJI 1997 memuat fasilitas semi perkotaan, jalan perkotaan, jalan luar kota dan jalan bebas hambatan dengan hasil analisis kinerja simpang menggunakan MKJI 1997 berupa nilai tundaan (D) dan derajat kejenuhan (DS). Sedangkan kinerja ruas jalan menghasilkan nilai derajat kejenuhan (DS) dan kecepatan (VLV) [8].

\section{METODE PENELITIAN}

\subsection{Lokasi Penelitian}

Penelitian dilakukan di Jalan Hayam Wuruk, Kec. Kaliwates, Kab. Jember yakni pada pembangunan Tanrise City Jember.

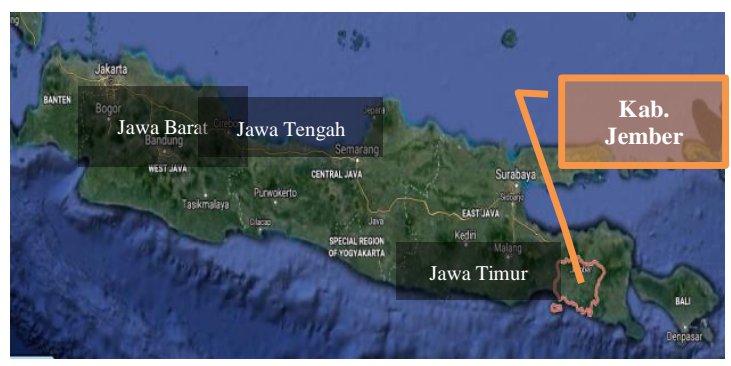

Gambar 1. Peta Kabupaten Jember

Kinerja simpang yang ditinjau yakni, Simpang Mangli, Simpang Argopuro dan Simpang Transmart. Lokasi penelitian dilihat pada gambar 2 . 


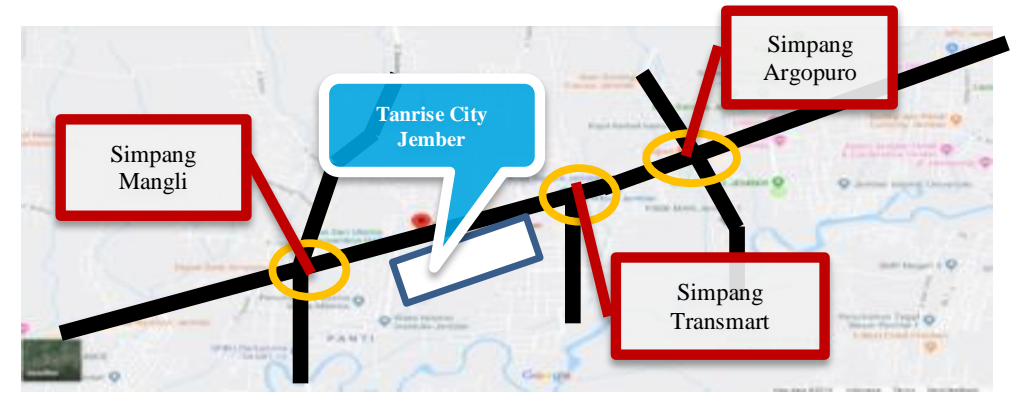

Gambar 2. Lokasi Penelitian (Tanrise City Jember)

Lokasi penelitian ruas jalan dapat dilihat pada gambar 3,4,5.

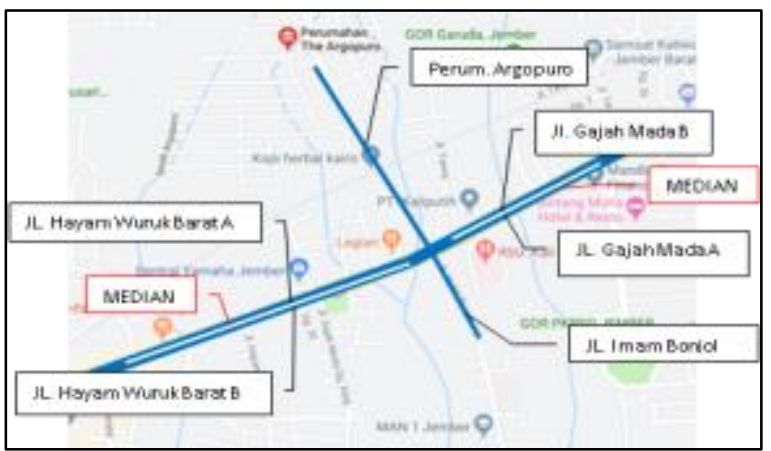

Gambar 3. Lokasi Segmen Ruas Jalan

Dekat Simpang Argopuro

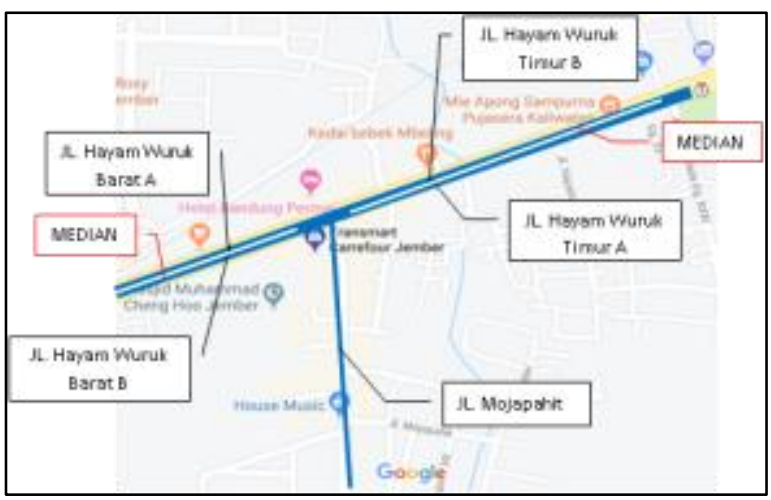

Gambar 4. Lokasi Segmen Ruas Jalan

Sebelah Timur Tanrise City Jember

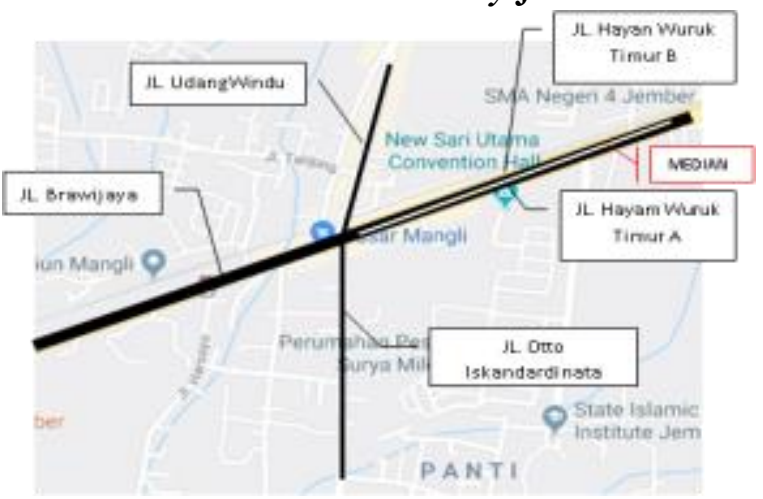

Gambar 5. Lokasi Segmen Ruas Jalan

Sebelah Barat Tanrise City Jember
Ruas jalan yang ditinjau dalam penelitian ini sesuai gambar 3, 4, 5 yakni ruas Jalan Imam Bonjol, Jalan Gajah Mada A dan B, Jalan Perum. Argopuro. Jalan Hayam Wuruk Barat A dan B, Jalan Hayam Wuruk Timur A dan B, Jalan Majapahit, Jalan Udang Windu, Jalan Brawijaya, dan Jalan Otto Iskandardinata.

\subsection{Tahapan -Tahapan dalam Penelitian}

Tahapan - tahapan yang dilakukan pada penelitian ini sebagai berikut:
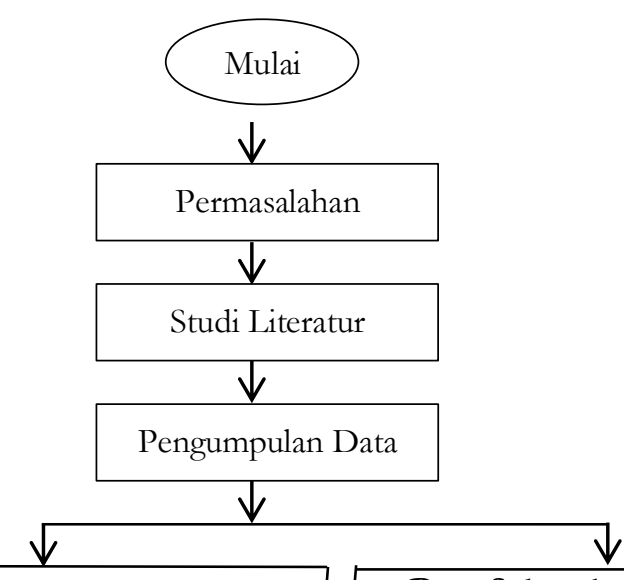

\section{Data Primer}

- Volume Simpang Mangli, Simpang Argopuro, Simpang Transmart, ruas Jl. Hayam Wuruk, Ruas disetiap lengan simpang

- Geometrik jalan Tanrise City Jember

- Jumlah bangkingan tarikan di Tanrise City Jember
Data Sekunder

- Masterplan Tanrise City Jember

- Jadwal Kegiatan pengembangan Tanrise City Jember 


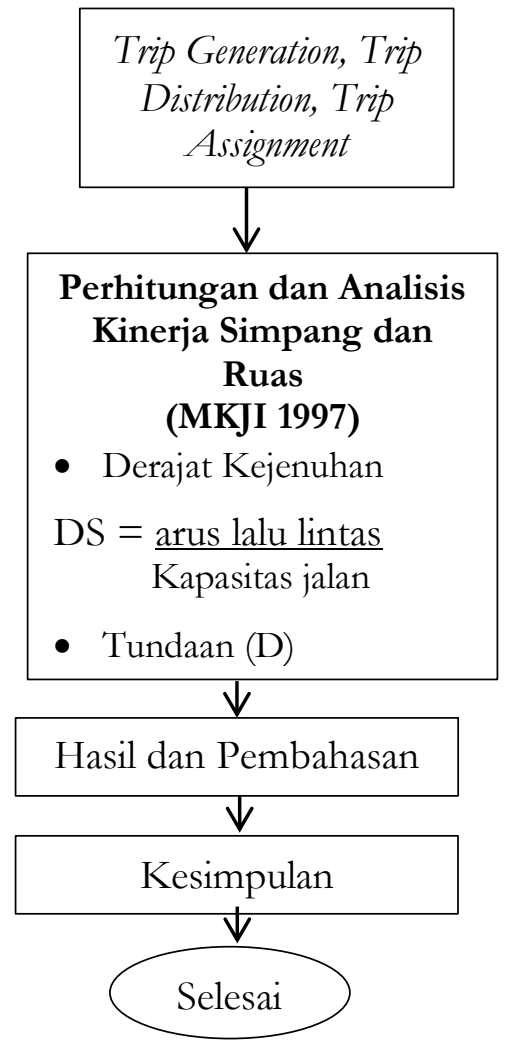

Gambar 6. Bagan Alir penelitian

\subsection{Bangunan Pembanding.}

Penentuan bangkitan dan tarikan perjalanan dilakukan dengan survei pada bangunan pembanding. Bangunan pembanding yang digunakan adalah bangunan yang memiliki fungsi yang sama dan memiliki karekteristik yang sejenis dengan bangunan pada Tanrise City Jember. Bangunan ruko Tanrise City Jember menggunakan pembanding ruko di area Diponegoro. Bangunan Convention hall menggunakan pembanding New Sari Utama convention hall. Depo Bangunan Jember dengan Depo Bangunan Malang, Pada bangunan mall dan hotel menggunakan pembanding Mall Lippo Plaza Jember dan Hotel Royal Jember. Perumahan Tanrise City Jember dibandingkan dengan Kliurang Green Garden, New Tegal Besar Clouster, dan Perumahan Istana Tegal Besar.

\subsection{Peralatan}

Alat - alat yang digunakan dalam penelitian ini yaitu roll meter, counter, alat tulis, form survei, walking distance, laptop dan kamera.

\subsection{Rencana Pengembangan Tanrise City Jember}

Pembangunan Tanrise City Jember dilakukan empat tahap dengan pembangunan awal dimulai pada tahun 2019 yakni pembangunan ruko dan depo bangunan. Bangunan yang ada di Tanrise City Jember diantaranya adalah mall, hotel, apartemen, perumahan dan convention hall.

\section{HASIL DAN PEMBAHSAN}

Dalam bab ini didapatkan hasil analisis trip generation, trip distribution, trip assignment, analisa kinerja simpang dan ruas. Perhitungan kinerja ruas dan simpang menggunakan MKJI 1997.

\subsection{Hasil Analisis Trip Generation}

Trip generation adalah tahapan pemodelan yang memperkirakan jumlah pergerakan yang berasal dari suatu zona atau tata guna lahan atau jumlah pergerakan yang tetarik ke suatu zona atau tata guna lahan [9]. Analisa trip production dan trip attraction dilakukan dengan survei pada bangunan pembanding yang memiliki fungsi bangunan yang sama dengan bangunan Tanrise City Jember. Survei dilakukan pada hari kerja selama bangunan beroperasi. Setelah dilakukan survei, dilakukan analisa untuk penentuan jam puncak di hari kerja. Jam puncak didapatkan berdasarkan penjumlahan tarikan dan bangkitan perjalanan bangunan pembanding yang terbesar selama waktu satu jam. Hasil perkiraan tarikan perjalanan dan bangkitan perjalanan dapat dilihat pada Tabel 1. 
Tabel 1. Hasil Perkiraan Tarikan dan Bangkitan pada Tanrise City Jember Hari Kerja.

\begin{tabular}{|c|c|c|c|c|c|c|c|c|}
\hline \multirow{3}{*}{ Kondisi } & \multirow{3}{*}{ Tahun } & \multirow{3}{*}{ Bangunan } & \multirow{3}{*}{ Jam Puncak } & \multirow{2}{*}{\multicolumn{2}{|c|}{ Tarikan }} & \multirow{2}{*}{\multicolumn{2}{|c|}{ Bangkitan }} & \multirow{3}{*}{$\begin{array}{c}\text { total } \\
\text { kend/jam }\end{array}$} \\
\hline & & & & & & & & \\
\hline & & & & MC & $\mathbf{L V}$ & MC & $\mathbf{L V}$ & \\
\hline \multirow{7}{*}{ Operasional } & \multirow[b]{2}{*}{2020} & Ruko & $8: 30$ - 9:30 & 10 & 9 & 11 & 5 & 35 \\
\hline & & $\begin{array}{l}\text { Depo } \\
\text { Bangunan } \\
\end{array}$ & 18:30 -19:30 & 4 & 22 & 5 & 25 & 56 \\
\hline & \multirow{2}{*}{2023} & Apartemen & $16: 00-17: 00$ & 5 & 8 & 5 & 7 & 25 \\
\hline & & Mall & $18: 15-19: 15$ & 4 & 25 & 6 & 23 & 58 \\
\hline & \multirow{2}{*}{2025} & Hotel & $14: 00-15: 00$ & 5 & 15 & 8 & 21 & 49 \\
\hline & & Convention & 20:00 - 21:00 & 1 & 17 & 4 & 108 & 130 \\
\hline & 2028 & Perumahan & $6: 30-8: 30$ & 60 & 46 & 74 & 46 & 226 \\
\hline \multirow{7}{*}{$\begin{array}{c}5 \text { tahun } \\
\text { Mendatang }\end{array}$} & \multirow[b]{2}{*}{2025} & Ruko & $8: 30-9: 30$ & 11 & 11 & 12 & 6 & 40 \\
\hline & & $\begin{array}{l}\text { Depo } \\
\text { Bangunan }\end{array}$ & $18: 30-19: 30$ & 4 & 27 & 6 & 30 & 67 \\
\hline & \multirow{2}{*}{2028} & Apartemen & $16: 00-17: 00$ & 5 & 8 & 5 & 8 & 26 \\
\hline & & Mall & 18:15 - 19:15 & 5 & 30 & 7 & 28 & 70 \\
\hline & \multirow{2}{*}{2030} & Hotel & $14: 00-15: 00$ & 6 & 18 & 9 & 26 & 59 \\
\hline & & Convention & 20:00 - 21:00 & 1 & 19 & 5 & 121 & 146 \\
\hline & 2033 & Perumahan & $6: 30-8: 30$ & 84 & 82 & 103 & 83 & 352 \\
\hline
\end{tabular}

\subsection{Hasil Analisis Trip Distribution}

Trip distribution menunjukkan jumlah perjalanan dari tiap asal ke tiap tujuan [10]. Pola perjalanan pengunjung dari dan menuju Tanrise City Jember dapat diketahui dengan menggunakan distribusi perjalanan. Analisis ditribusi perjalanan dilakukan dengan melakukan pembagian zona tarikan perjalanan dan bangkitan perjalanan lalu lintas. Pembagian zona Tanrise City Jember dapat dilihat pada gambar 7 .

\subsection{Hasil Analisis Trip Assignment}

Prediksi beban lalu lintas didapatkan melalui pergerakan perjalanan dari dan menuju lokasi Tanrise City Jember dengan rute terpendek. Persentase pembebanan setiap zona diperoleh dengan pendekatan jumlah penduduk kecamatan terdekat dan berasal dari masing - masing zona bangkitan tarikan. Hasil persentase pembebanan ditunjukkan pada gambar 8 .

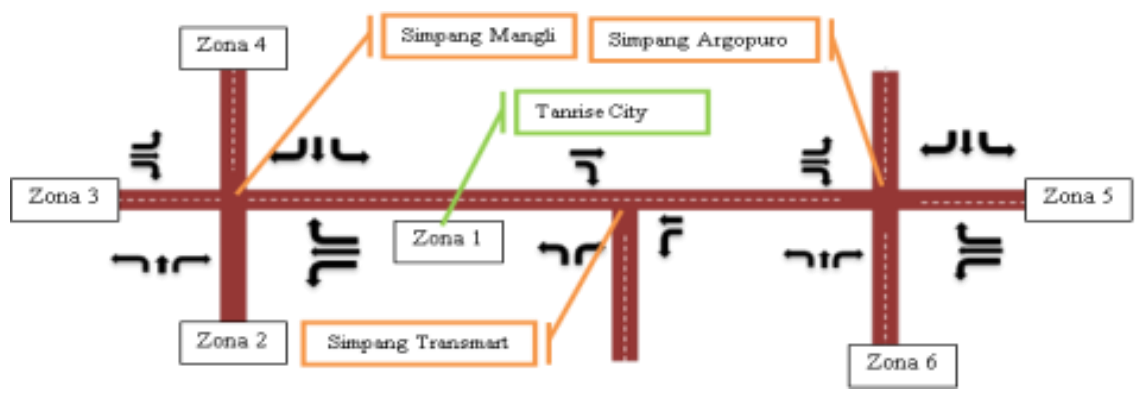

Gambar 7. Pembagian Zona Bangkitan dan Tarikan Tanrise City Jember 


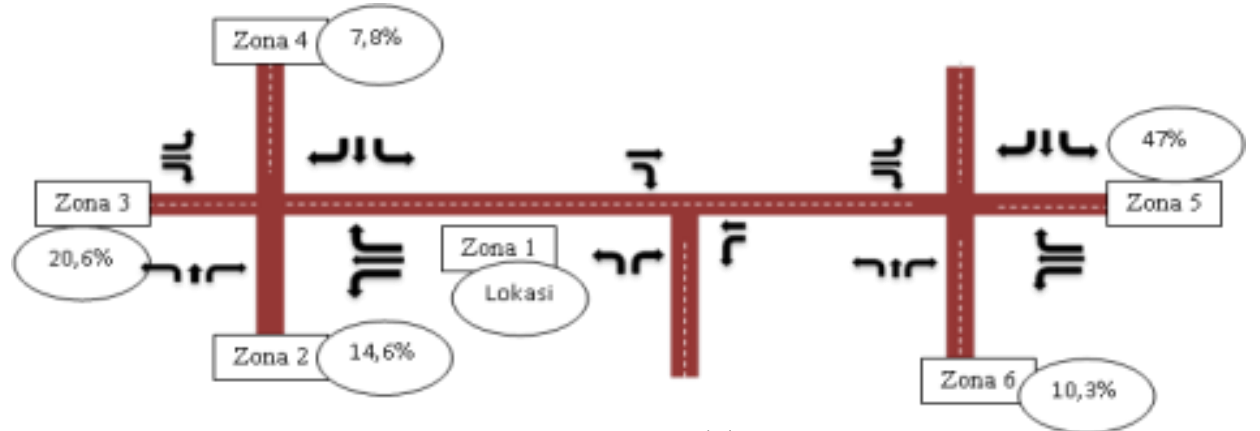

Gambar 8. Nilai Persentase Beban Tarikan dan Perjalanan

Keterangan:
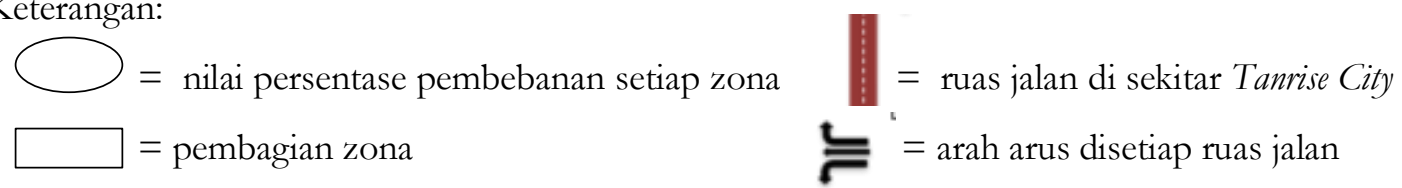

\section{Tabel 2. MAT Hari Kerja (smp/jam)}

Nilai persentase yang dihasilkan kemudian dikalikan dengan bangkitan dan tarikan perjalanan setiap bangunan sesuai zonasinya.Pendistribusian beban kendaraan dimodelkan dalam Matrik Asal Tujuan (MAT) dengan satuan smp/jam. Salah satu contoh hasil pendistribusian beban lalu lintas ditunjukkan pada Tabel 2.

\section{4}

\begin{tabular}{cccccccc}
\hline tij & $\mathbf{1}$ & $\mathbf{2}$ & $\mathbf{3}$ & $\mathbf{4}$ & $\mathbf{5}$ & $\mathbf{6}$ & Tot \\
\hline $\mathbf{1}$ & 0 & 3 & 4 & 2 & 9 & 2 & $\mathbf{2 0}$ \\
$\mathbf{2}$ & 4 & 0 & 228 & 161 & 197 & 22 & $\mathbf{6 1 2}$ \\
$\mathbf{3}$ & 5 & 373 & 0 & 255 & 1633 & $\mathbf{1 7 0}$ & $\mathbf{2 4 3 5}$ \\
$\mathbf{4}$ & 2 & 160 & 167 & 0 & 51 & 6 & $\mathbf{3 8 6}$ \\
$\mathbf{5}$ & 11 & 405 & 1002 & 184 & 0 & 75 & $\mathbf{1 6 7 6}$ \\
$\mathbf{6}$ & 2 & 101 & 226 & 50 & 110 & 0 & $\mathbf{4 8 9}$ \\
Tot & $\mathbf{2 4}$ & $\mathbf{8}$ & $\mathbf{1 6 2 6}$ & $\mathbf{6 5 1}$ & $\mathbf{2 0 0 1}$ & $\mathbf{2 7 5}$ & $\mathbf{5 6 1 8}$ \\
\hline
\end{tabular}

pang

Hasil kinerja simpang kondisi eksisting merupakan kondisi sebelum adanya pembangunan Tanrise City Jember yakni tahun 2019. Hasil kinerja simpang tersebut menggunakan volume kendaraan dengan metode MKJI 1997 dapat dilihat pada tabel 3. Menunjukkan nilai tundaan (D) terbesar terjadi di Simpang Mangli dengan nilai tundaan pada jam puncak 6:30 - 7:30 mencapai 1417,23 det/smp. Sedangkan simpang Transmart dan Argopuro tidak memiliki nilai tundaan hingga 1000 det/smp. Hal ini menunjukkan kinerja simpang paling buruk terjadi pada Simpang Mangli.

Tabel 3. Kinerja Simpang Kondisi Eksisting

\begin{tabular}{|c|c|c|c|c|c|c|c|c|}
\hline \multirow{3}{*}{ No } & \multirow{3}{*}{$\begin{array}{l}\text { Simpang dan } \\
\text { Lengan } \\
\text { Simpang }\end{array}$} & \multicolumn{7}{|c|}{ Jam Puncak } \\
\hline & & $6: 30-7: 30$ & $\begin{array}{r}8: 30- \\
9: 30\end{array}$ & $\begin{array}{r}14: 00- \\
15: 00\end{array}$ & $\begin{array}{r}16: 00- \\
17: 00\end{array}$ & $\begin{array}{l}18: 15- \\
19: 15\end{array}$ & $\begin{array}{l}18: 30- \\
19: 30\end{array}$ & $\begin{array}{l}20: 00- \\
21: 00\end{array}$ \\
\hline & & $\begin{array}{c}\text { D } \\
\text { det/smp }\end{array}$ & $\begin{array}{c}\text { D } \\
\text { det/smp }\end{array}$ & $\begin{array}{c}\text { D } \\
\text { det/smp }\end{array}$ & $\begin{array}{c}\text { D } \\
\text { det/smp }\end{array}$ & $\begin{array}{c}\text { D } \\
\text { det/smp }\end{array}$ & $\begin{array}{c}\text { D } \\
\text { det/smp }\end{array}$ & $\begin{array}{c}\text { D det/ } \\
\text { smp }\end{array}$ \\
\hline 1 & Simpang Mangli & 1417,23 & 1217,17 & 452,38 & 948,75 & 371,10 & 294,32 & 45,30 \\
\hline 2 & $\begin{array}{l}\text { Simpang } \\
\text { Argopuro }\end{array}$ & 531,09 & 167,49 & 255,36 & 181,80 & 241,22 & 71,42 & 29,42 \\
\hline 3 & $\begin{array}{l}\text { Simpang } \\
\text { Transmart }\end{array}$ & 142,11 & 217,23 & 240,48 & 523,06 & 80,28 & 318,27 & 42,79 \\
\hline
\end{tabular}


Hasil analisis kinerja simpang kondisi operasional hari kerja menggunakan metode MKJI 1997 dapat dilihat pada tabel 4. Operasional terjadi tahun 2020 dimana pembangunan tahap 1 selesai, tahap 2 selesai tahun 2023 dan tahap 3 selesai tahun 2025. Seluruh bangunan Tnrise City Jember beroperasi pada tahun 2028 dimana pembangunan tahap 4 telah selesai pada tahun tersebut. Volume lalu lintas tahun operasional didapatkan dari faktor pertumbuhan kendaraan dikalikan volume lalu lintas awal, kemudian dijumlahkan dengan bangkitan dan tarikan perjalanan Tanrise City Jember.

Tabel 4. Hasil Analisa Kinerja Simpang Kondisi Operasional (Hari Kerja)

\begin{tabular}{|c|c|c|c|c|c|c|c|}
\hline \multirow[t]{2}{*}{ Simpang } & $6: 30-7: 30$ & $8: 30-9: 30$ & $\begin{array}{r}14: 00- \\
15: 00\end{array}$ & $\begin{array}{r}\text { am Puncal } \\
16: 00- \\
17: 00\end{array}$ & $\begin{array}{l}18: 15- \\
19: 15\end{array}$ & $\begin{array}{l}18: 30- \\
19: 30\end{array}$ & $\begin{array}{l}20: 00- \\
21: 00\end{array}$ \\
\hline & $\begin{array}{c}\mathrm{D} \\
(\mathrm{det} / \mathrm{smp})\end{array}$ & $\begin{array}{c}\mathrm{D} \\
\text { (det/smp) }\end{array}$ & $\begin{array}{c}\mathrm{D} \\
\text { (det/smp) }\end{array}$ & $\begin{array}{c}\mathrm{D} \\
(\mathrm{det} / \mathrm{smp})\end{array}$ & $\begin{array}{c}\mathrm{D} \\
(\mathrm{det} / \mathrm{smp})\end{array}$ & $\begin{array}{c}\mathrm{D} \\
(\mathrm{det} / \mathrm{smp})\end{array}$ & $\begin{array}{c}\mathrm{D} \\
\text { (det/smp) }\end{array}$ \\
\hline Tahun 2020 & & & & & & & \\
\hline $\begin{array}{l}\text { Simpang Mangli } \\
\text { Simpang }\end{array}$ & 1451,35 & 1308,19 & 511,54 & 1051,88 & 414,91 & 340,09 & 46,21 \\
\hline $\begin{array}{l}\text { Argopuro } \\
\text { Simpang }\end{array}$ & 576,95 & 182,70 & 282,57 & 199,77 & 115,64 & 81,44 & 29,76 \\
\hline Transmart & 159,81 & 222,59 & 283,31 & 600,26 & 96,99 & 345,51 & 44,29 \\
\hline Tahun 2023 & & & & & & & \\
\hline $\begin{array}{l}\text { Simpang Mangli } \\
\text { Simpang }\end{array}$ & 1766,34 & 1582,78 & 728,19 & 1318,15 & 576,42 & 497,65 & 50,34 \\
\hline $\begin{array}{l}\text { Argopuro } \\
\text { Simpang }\end{array}$ & 743,05 & 276,33 & 374,63 & 421,58 & 372,28 & 117,08 & 38,21 \\
\hline Transmart & 263,90 & 346,71 & 378,30 & 786,39 & 202,16 & 468,59 & 48,22 \\
\hline Tahun 2025 & & & & & & & \\
\hline $\begin{array}{l}\text { Simpang Mangli } \\
\text { Simpang }\end{array}$ & 2023,69 & 1824,72 & 908,71 & 1527,11 & 706,17 & 629,00 & 57,64 \\
\hline $\begin{array}{l}\text { Argopuro } \\
\text { Simpang }\end{array}$ & 882,73 & 404,87 & 504,22 & 558,57 & 133,42 & 148,12 & 264,13 \\
\hline Transmart & 342,68 & 370,69 & 523,22 & 917,69 & 280,47 & 572,05 & 49,11 \\
\hline Tahun 2028 & & & & & & & \\
\hline $\begin{array}{l}\text { Simpang Mangli } \\
\text { Simpang }\end{array}$ & 2400,09 & 2033,40 & 1046,07 & 1885,40 & 820,28 & 740,79 & 68,80 \\
\hline $\begin{array}{l}\text { Argopuro } \\
\text { Simpang }\end{array}$ & $1.020,38$ & 614,34 & 601,25 & $1.073,82$ & 208,31 & 148,12 & 264,13 \\
\hline Transmart & 463,26 & 514,89 & 613,61 & $1.021,66$ & 352,19 & 662,16 & 51,71 \\
\hline
\end{tabular}

Pada tabel 4. hasil analisis dengan MKJI 1997 menunjukkan nilai tundaan (D) terbesar terjadi di Simpang Mangli. Hal ini karena nilai tundaan pada beberapa jam puncak disetiap tahun operasionalnya mencapai lebih dari $1000 \mathrm{det} / \mathrm{smp}$ bahkan mencapai 2400,09 det/smp pada jam puncak 06.30 -17.00. Maka, Simpang Mangli termasuk dalam kategori LoS F. Kinerja simpang tidak stabil dan volume 
kendaraan pada simpang melebihi kapasitas.

Hasil analisis kinerja simpang lima tahun mendatang adalah kondisi bangunan telah beroperasi selama lima tahun. Lima tahun mendatang untuk bangunan ruko dan depo terjadi tahun 2025. Bangunan mall dan apartemen terjadi pada tahun 2028. Lima tahun mendatang untuk bangunan hotel, convention hall tahun 2030 dan perumahan terjadi tahun 2033. Volume lalu lintas tahun 2033 didapatkan dari faktor pertumbuhan yang dikalikan volume lalu lintas aawal kemudian dijumlahkan dengan beban bangkitan tarikan Tanrise City jember. Berikut hasil analisis kinerja simpang pada kondisi lima tahun mendatang terjadi pada hari kerja ditunjukkan pada Tabel 5.

Tabel 5. Hasil Analisis Kinerja simpang Kondisi 5 Tahun Mendatang (Hari Kerja)

\begin{tabular}{|c|c|c|c|c|c|c|c|}
\hline \multirow{3}{*}{ Simpang } & \multicolumn{7}{|c|}{ Jam Puncak } \\
\hline & $6: 30-7: 30$ & $8: 30-9: 30$ & $\begin{array}{r}14: 00- \\
15: 00\end{array}$ & $\begin{array}{r}16: 00- \\
17: 00\end{array}$ & $\begin{array}{l}18: 15- \\
19: 15\end{array}$ & $\begin{array}{l}18: 30- \\
19: 30\end{array}$ & $\begin{array}{l}\text { 20:00 - } \\
\text { 21:00 }\end{array}$ \\
\hline & $\begin{array}{c}\mathrm{D} \\
\text { (det/smp) }\end{array}$ & $\begin{array}{c}\mathrm{D} \\
\text { (det/smp) }\end{array}$ & $\begin{array}{c}\mathrm{D} \\
\text { (det/smp) }\end{array}$ & $\begin{array}{c}\mathrm{D} \\
\text { (det/smp) }\end{array}$ & $\begin{array}{c}\mathrm{D} \\
\text { (det/smp) }\end{array}$ & $\begin{array}{c}\mathrm{D} \\
\text { (det/smp) }\end{array}$ & $\begin{array}{c}\mathrm{D} \\
\text { (det/smp) }\end{array}$ \\
\hline \multicolumn{8}{|c|}{ Tahun 2025} \\
\hline $\begin{array}{l}\text { Simpang Mangli } \\
\text { Simpang }\end{array}$ & 2023,69 & 1824,72 & 908,71 & 1939,93 & 706,17 & 375,82 & 57,64 \\
\hline $\begin{array}{l}\text { Argopuro } \\
\text { Simpang }\end{array}$ & 882,73 & 404,87 & 504,22 & 558,57 & 133,42 & 148,12 & 264,13 \\
\hline Transmart & 342,68 & 370,69 & 523,22 & 917,69 & 280,47 & 572,05 & 49,11 \\
\hline \multicolumn{8}{|c|}{ Tahun 2028} \\
\hline $\begin{array}{l}\text { Simpang Mangli } \\
\text { Simpang }\end{array}$ & 2400,09 & 1466,21 & 604,65 & 1313,88 & 464,67 & 375,82 & 68,80 \\
\hline $\begin{array}{l}\text { Argopuro } \\
\text { Simpang }\end{array}$ & 1020,38 & 614,34 & 601,25 & 1073,82 & 208,31 & 148,12 & 264,13 \\
\hline Transmart & 463,26 & 514,89 & 613,61 & 1021,66 & 352,19 & 662,16 & 51,71 \\
\hline \multicolumn{8}{|c|}{ Tahun 2030} \\
\hline Simpang Mangli & 2391,27 & 1696,62 & 777,76 & 1396,11 & 574,22 & 489,51 & 110,40 \\
\hline $\begin{array}{l}\text { Simpang } \\
\text { Argopuro } \\
\text { Simpang }\end{array}$ & 1195,38 & 767,58 & 754,62 & 730,32 & 337,15 & 223,95 & 319,42 \\
\hline Transmart & 560,47 & 619,21 & 739,14 & 1177,46 & 439,50 & 684,32 & 59,79 \\
\hline \multicolumn{8}{|l|}{ Tahun 2033} \\
\hline $\begin{array}{l}\text { Simpang Mangli } \\
\text { Simpang }\end{array}$ & 2438,27 & 2281,64 & 1051,68 & 1747,89 & 763,20 & 686,95 & 225,49 \\
\hline $\begin{array}{l}\text { Argopuro } \\
\text { Simpang }\end{array}$ & 1487,82 & $1.028,79$ & $1.007,22$ & 1132,24 & 555,10 & 424,89 & 412,02 \\
\hline Transmart & 433,80 & 580,05 & 947,14 & 1476,59 & 595,36 & 983,11 & 66,02 \\
\hline
\end{tabular}

Pada tabel 6. menunjukkan nilai tundaan pada tahun 2025, 2028, 2030, dan tahun 2033 terbesar terjadi di Simpang Mangli dengan nilai tundaan pada beberapa jam puncak mencapai $>2000$ $\mathrm{det} / \mathrm{smp}$ jam puncak pagi. Tahun 2025 nilai tundaan sebesar 2023,69 det/smp, tahun 2028 sebsar 2400,09 det/smp, tahun 2030 sebesar 2391,27 det/smp dan tahun 2033 sebesar 234,27 det.smp. Hal ini menunjukkan bahwa kinerja Simpang Mangli buruk dan volume kendaraan 
melebihi kapsitas. Kenaikan kinerja simpang setiap tahunnya dapat di lihat pada kinerja simpang semua kondisi yakni kondisi eksisting, operasional dan 5 tahun mendatang. Berdasarkan gambar 8 Simpang Mangli memiliki persentase tundaan rata - rata diatas $40 \%$ sedangkan simpang lainnya dibawah 30\%. Dilihat pada gambar 8. setiap tahunnya Simpang Mangli mengalami kenaikan sebesar 21\%. Nilai persentase $40 \%$ menunjukkan nilai tundaan ada yang mencapai $1000 \mathrm{det} / \mathrm{smp}$ bahkan lebih dari 2000 det/smp. Persentase kenaikan dan hasil persentase kinerja simpang semua kondisi dapat dilihat pada gambar 9 dan 10 .

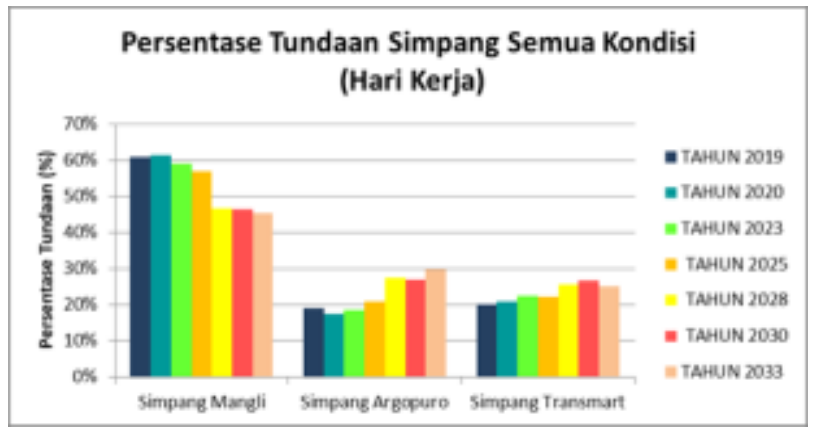

Gambar 9. Persentase Tundaan Simpang

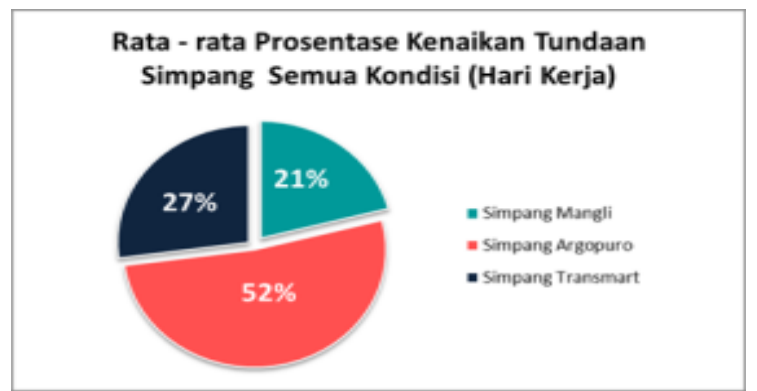

Gambar 10. Persentase Rata-Rata Kenaikan Tundaan

\subsection{Hasil Analisis Kinerja Ruas}

Hasil kinerja ruas dengan metode MKJI 1997 setiap tahun kondisi eksisting, operasional dan lima tahun mendatang pada hari kerja dapat dilihat pada gambar 11 S.d 17. Pada gambar tersebut hasil kinerja setiap tahunnya yang berupa nilai derajat kejenuhan (DS) pada hari kerja menunjukkan nilai DS meningkat. Nilai DS pada kondisi eksisiting adalah arus stabil. Kinerja ruas terburuk terjadi pada Jl. Brawijaya dengan derajat kejenuhan (DS) > 0,85, menunjukkan kondisi simpang mulai tidak stabil. Pada kondisi operasional dan 5 tahun mendatang kinerja ruas terburuk terjadi pada Jl. Brawijaya dengan DS $>1$ pada jam puncak 06.30 - 07.30. Ketentuan kinerja ruas baik atau tidak, derdasarkan nilai DS dapat dilihat pada tabel 6. Jl. Brawijaya termasuk dalam tingkat pelayanan $\mathrm{E}$ dan $\mathrm{F}$.

Tabel 6. Tingkat Pelayanan Jalan

\begin{tabular}{|c|l|c|}
\hline $\begin{array}{c}\text { Tingkat } \\
\text { Pelayanan }\end{array}$ & \multicolumn{1}{|c|}{$\begin{array}{c}\text { Karakteristik Lalu } \\
\text { Lintas }\end{array}$} & $\begin{array}{c}\text { Batas } \\
\text { Lingkup DS }\end{array}$ \\
\hline A & $\begin{array}{l}\text { Kondisi lalu lintas bebas } \\
\text { dengan kecepatan tinggi } \\
\text { dan volume lalu lintas } \\
\text { rendah }\end{array}$ & $0,00-0,19$ \\
\hline B & $\begin{array}{l}\text { Arus stabil, kecepatan } \\
\text { operasi mulai dibatasi } \\
\text { oleh kondisi lalu lintas. }\end{array}$ & $0,20-0,49$ \\
\hline C & $\begin{array}{l}\text { Arus stabil, kecepatan } \\
\text { dan gerak kendaraan } \\
\text { dikendalikan }\end{array}$ & $0,50-0,69$ \\
\hline D & $\begin{array}{l}\text { Arus mendekati tidak } \\
\text { stabil, kecepatan masih } \\
\text { dapat dikendalikan, } \\
\text { volume pelayanan } \\
\text { berkaitan dengan } \\
\text { kapasitas dapat ditolirer. }\end{array}$ & $0,70-0,84$ \\
\hline E & $\begin{array}{l}\text { Arus tidak stabil, } \\
\text { kecepatan terkadang } \\
\text { terhenti, volume lalu } \\
\text { lintas berada pada } \\
\text { kapasitasnya. }\end{array}$ & $0,85-1,00$ \\
\hline F & $\begin{array}{l}\text { Arus tidak stabil, } \\
\text { kecepatan rendah, } \\
\text { volume diatas kapasitas, } \\
\text { antrian panjang (macet) }\end{array}$ & $>1,00$ \\
\hline Trafic Planaing and \\
\hline
\end{tabular}

Sumber : Traffic Planning and Engineering, 2nd Edition Pergamon Press 


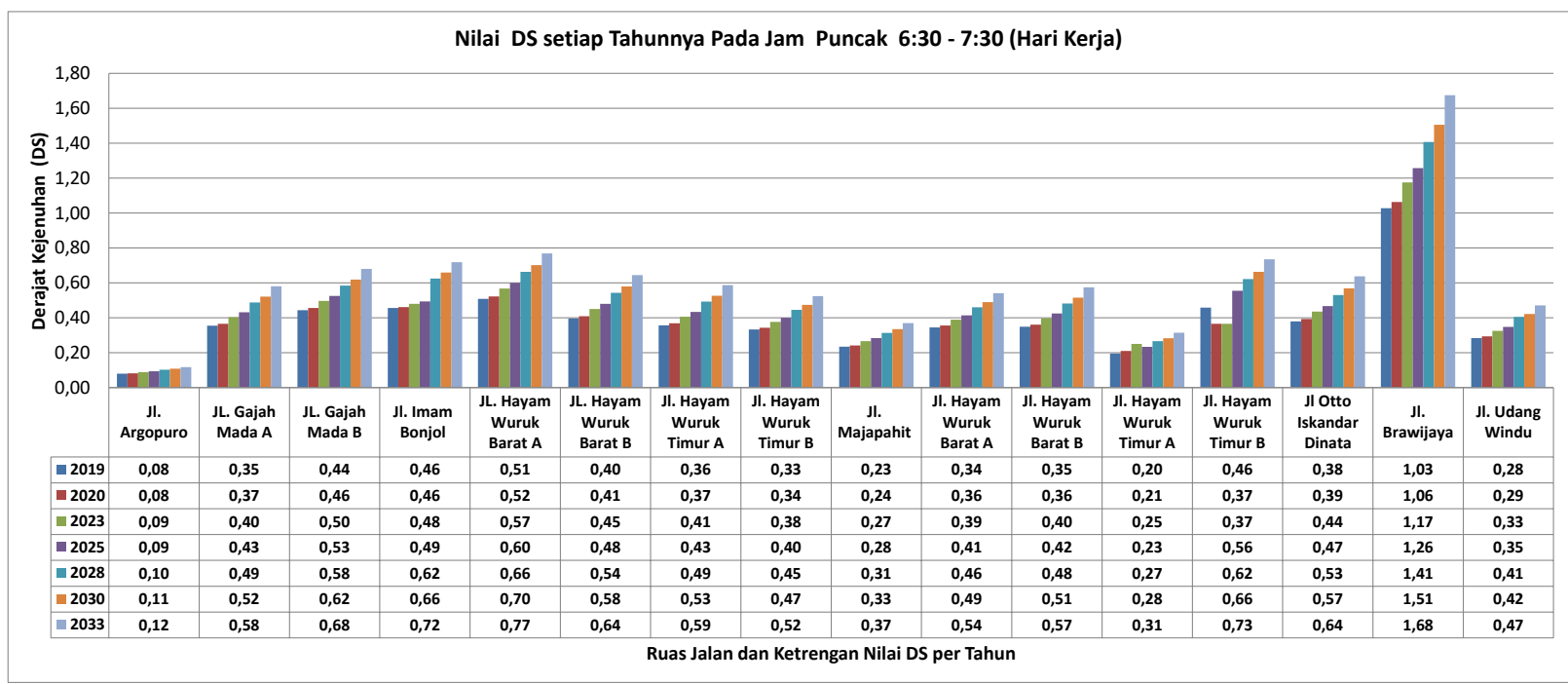

Gambar 11. Nilai DS Setiap Tahunnya Pada jam Puncak 6:30 - 7:30 (Hari Kerja)

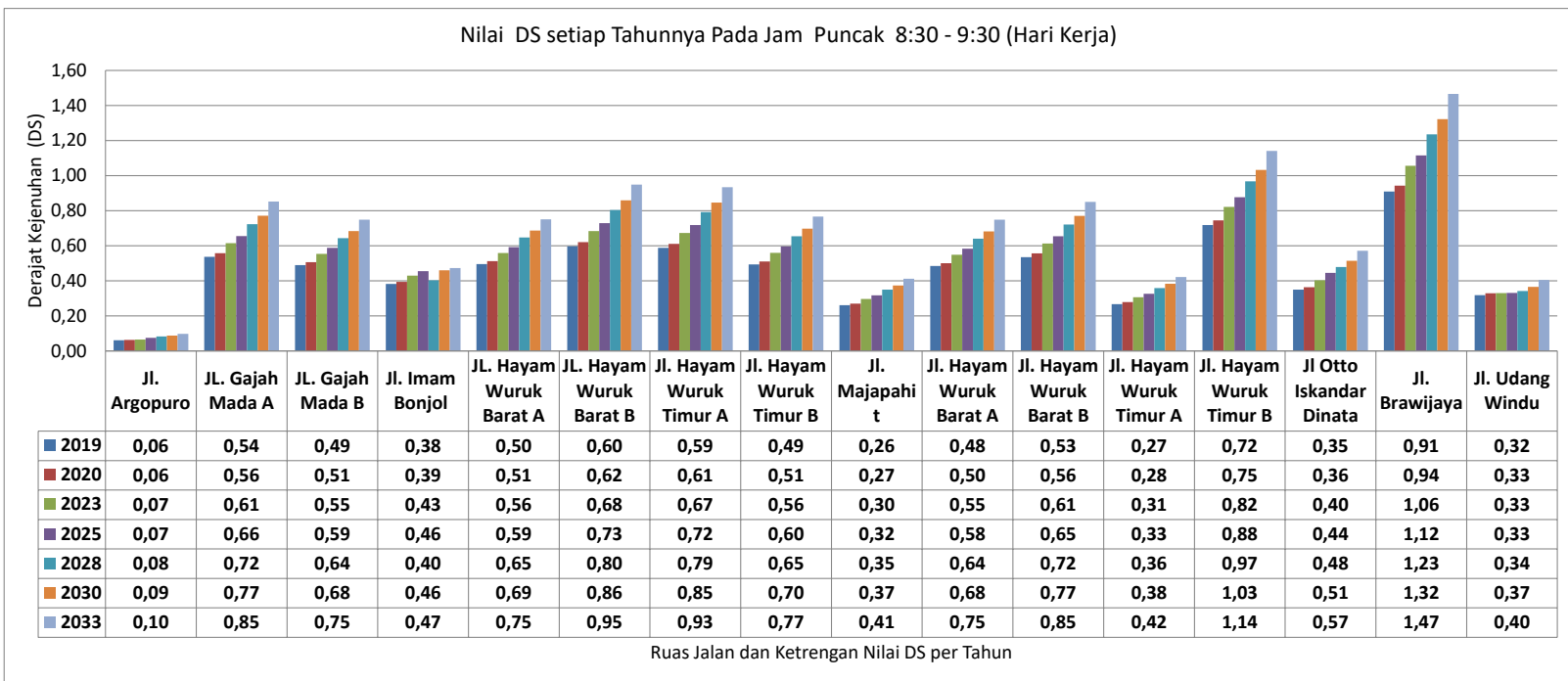

Gambar 12. Nilai DS Setiap Tahunnya Pada jam Puncak 8:30 - 9:30 (Hari Kerja)

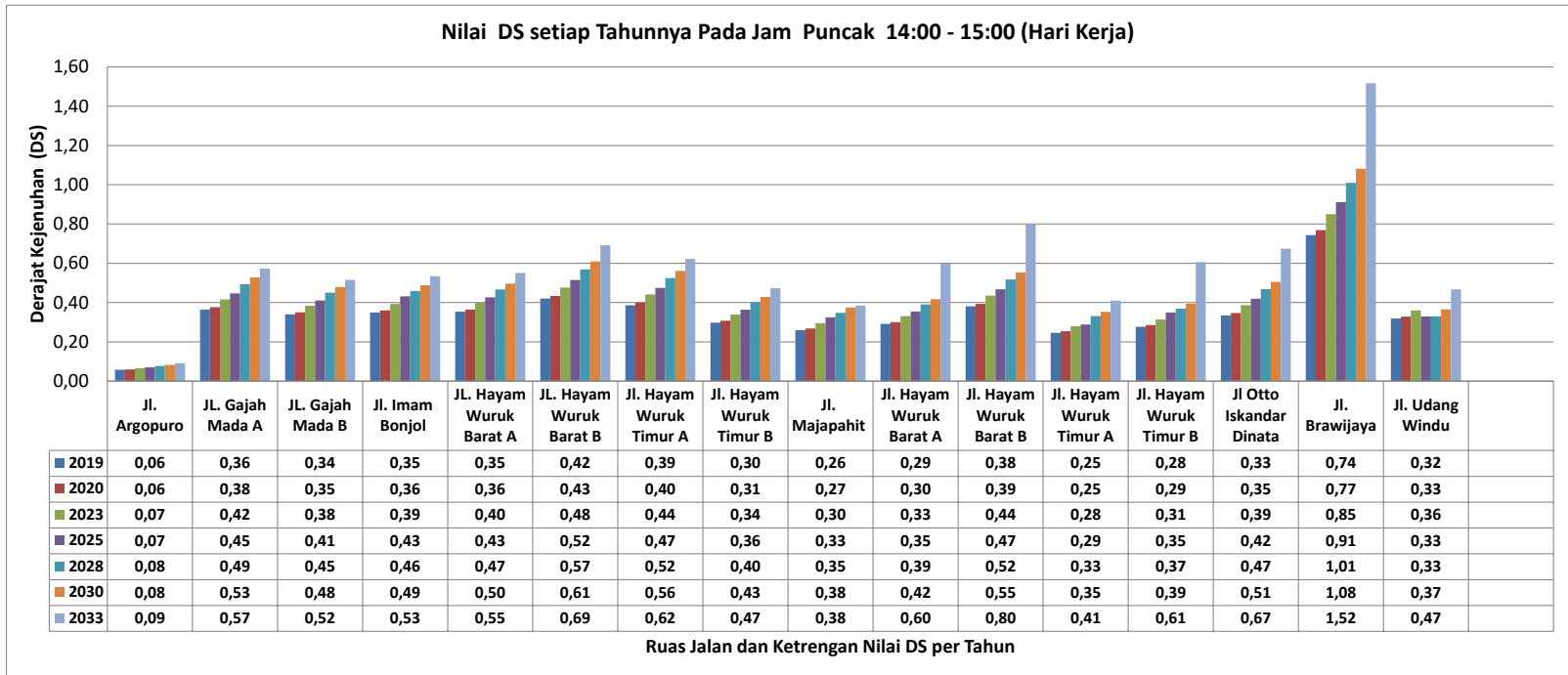

Gambar 13. Nilai DS Setiap Tahunnya Pada jam Puncak 14:00 - 15:00 (Hari Kerja) 
Reka Buana : Jurnal Ilmiah Teknik Sipil dan Teknik Kimia, 5(2), 2020, page 112-124

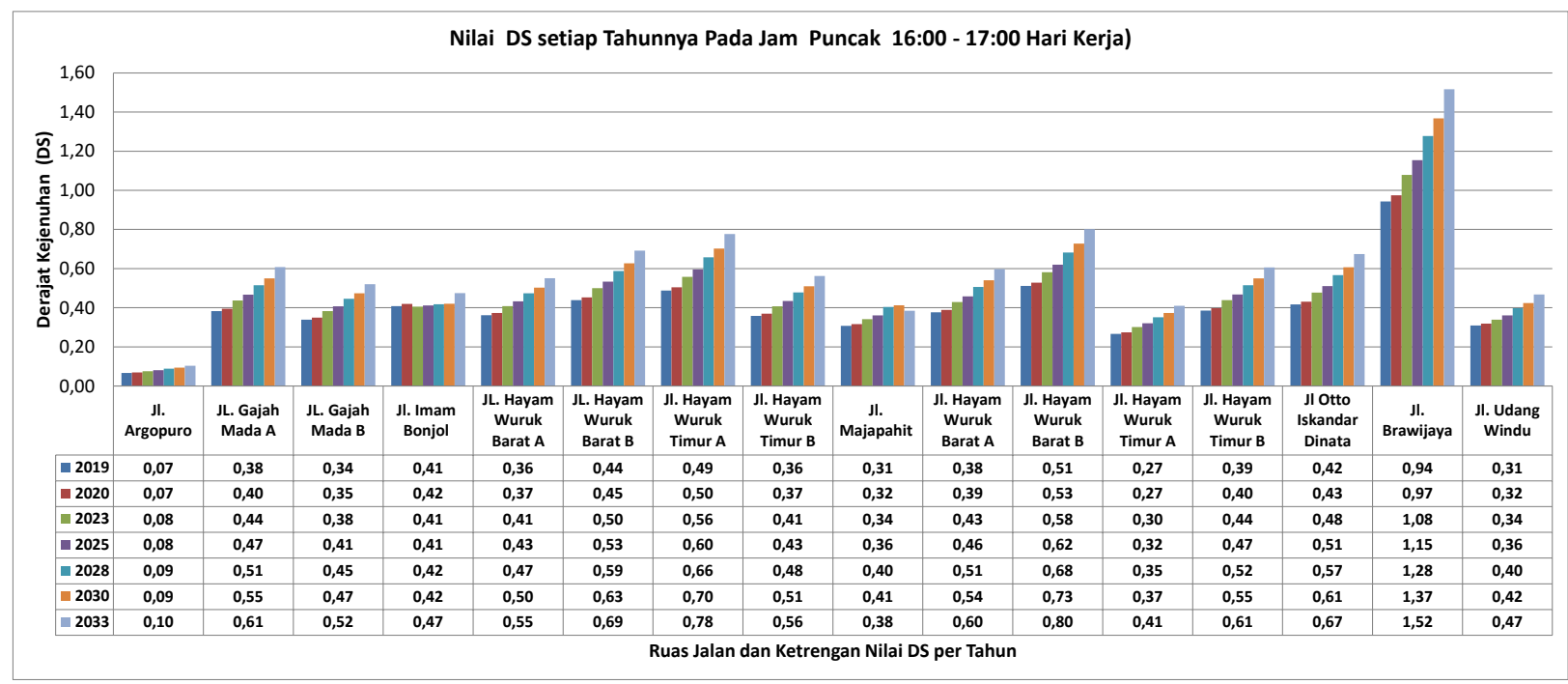

Gambar 14. Nilai DS Setiap Tahunnya Pada jam Puncak 16:00 - 17:00 (Hari Kerja)

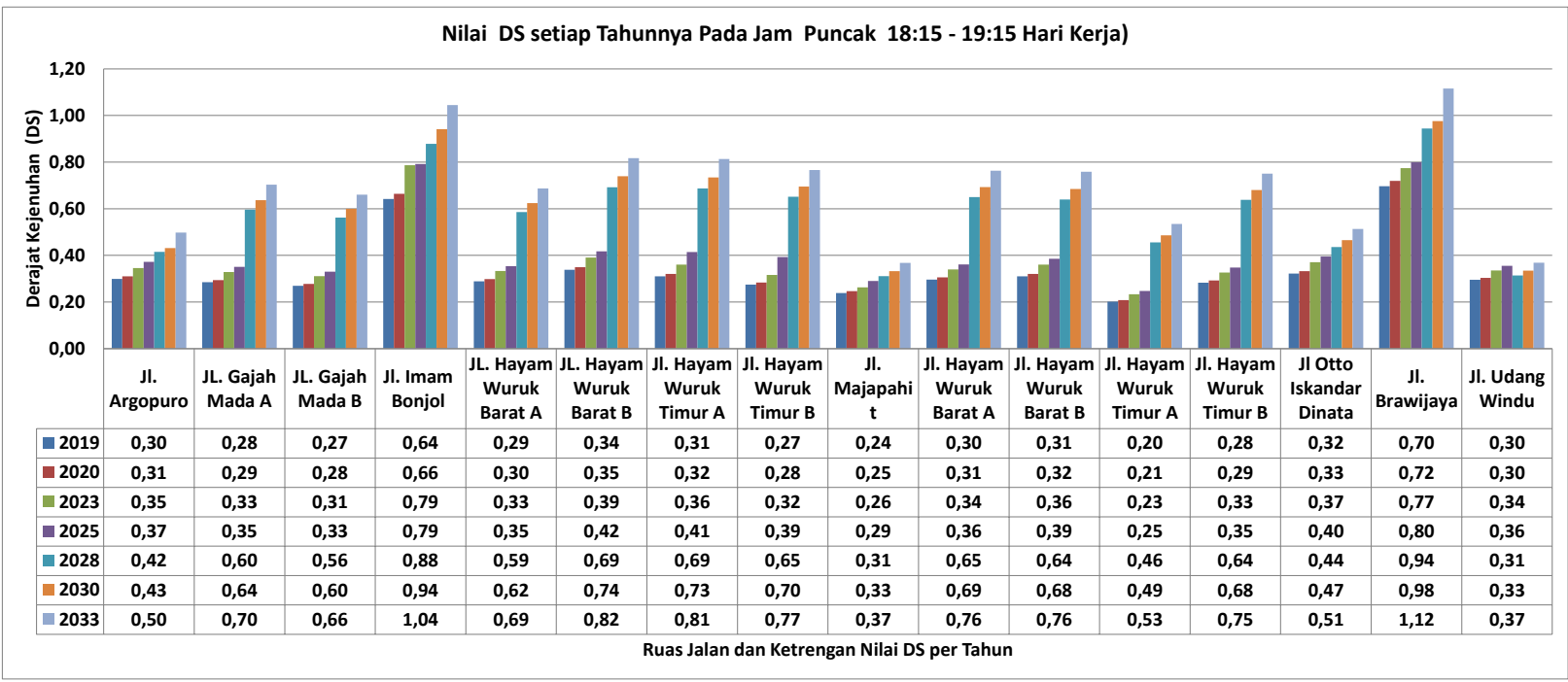

Gambar 15. Nilai DS Setiap Tahunnya Pada jam Puncak 18:15 -19:15 (Hari Kerja)

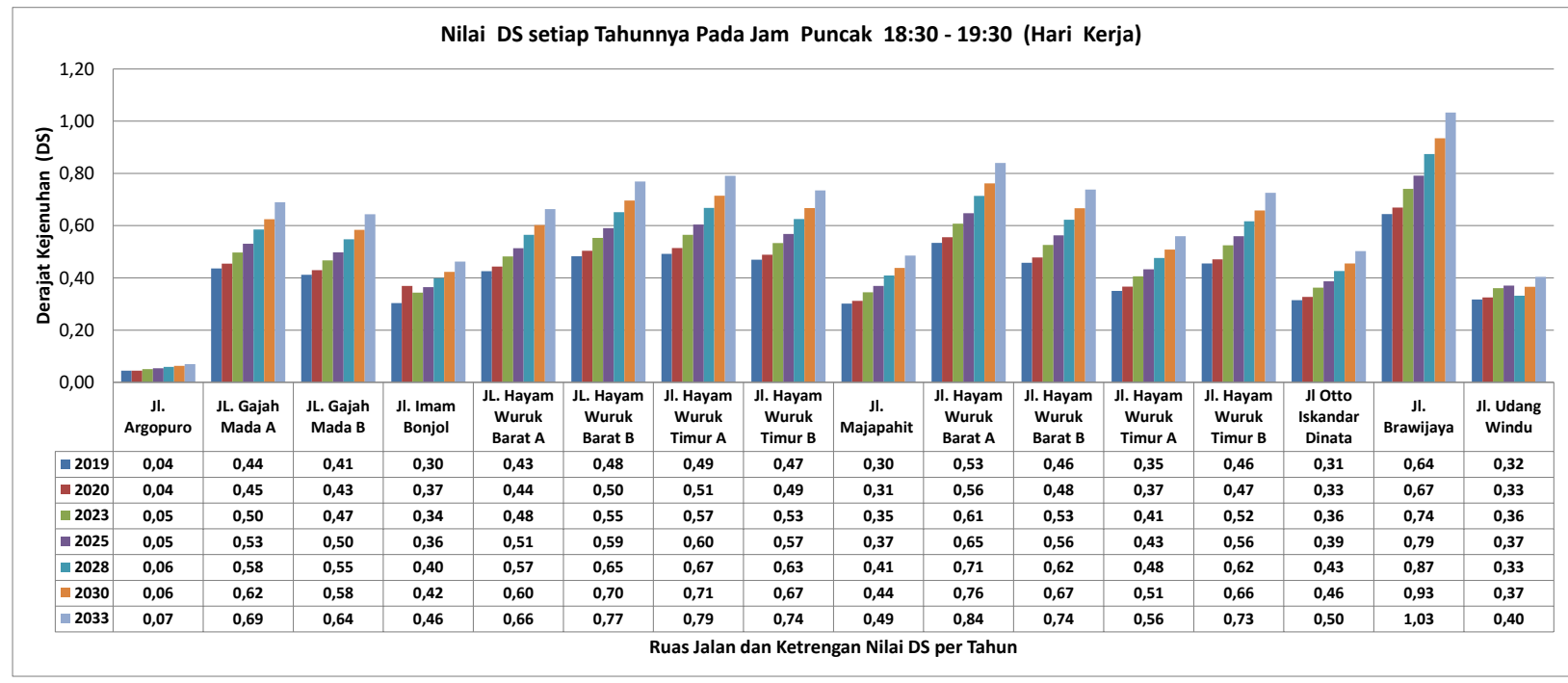

Gambar 16. Nilai DS Setiap Tahunnya Pada jam Puncak 18:30 -19:30 (Hari Kerja) 


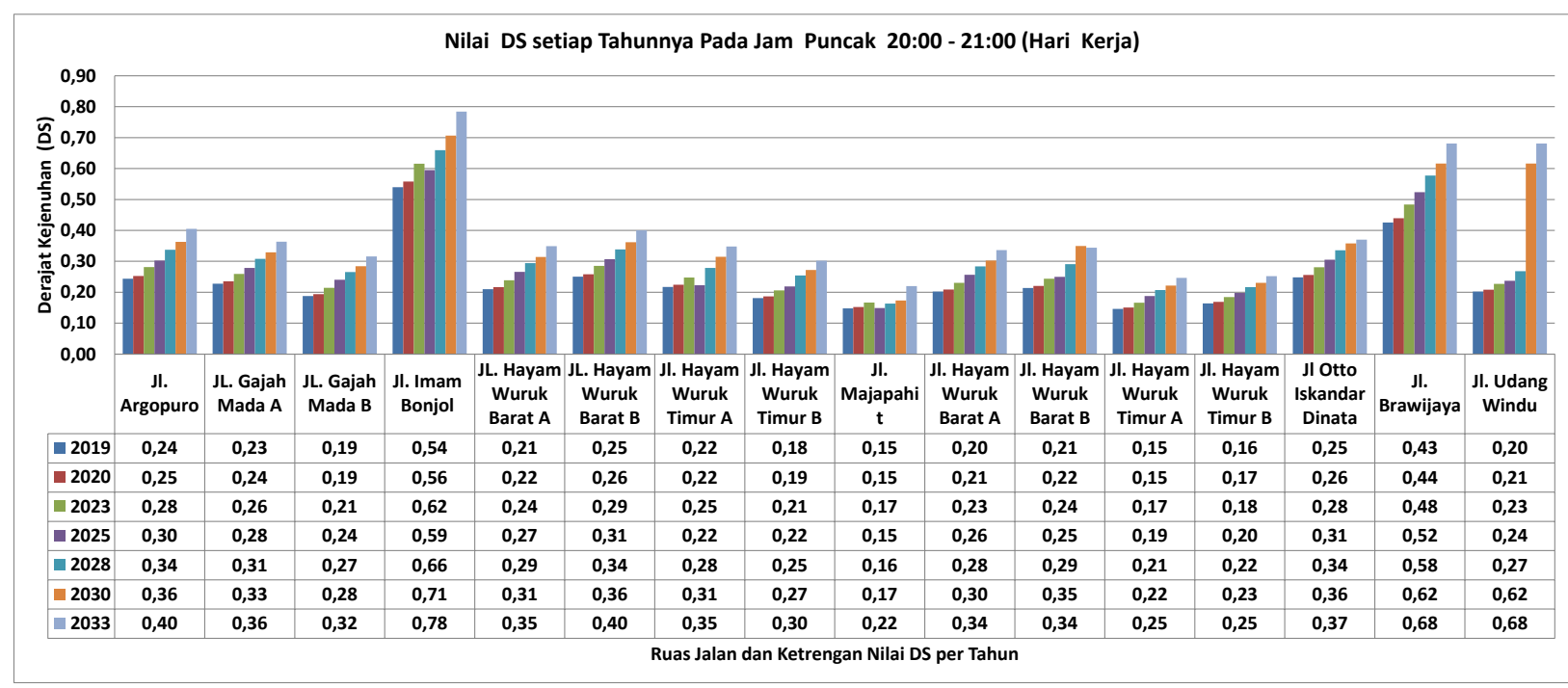

Gambar 17. Nilai DS Setiap Tahunnya Pada jam Puncak 20:00 - 21:00 (Hari Kerja)

\subsection{Pembahasan}

Hasil analisis kinerja simpang kondisi eksisting tahun 2019 dengan metode MKJI 1997 sebelum pembangunan Tanrise City Jember terburuk terjadi pada Simpang Mangli jam puncak 06.30 - 07.30. Nilai tundaan mencapai 1417,23 det/smp masuk dalam kategoi LoS F.

Hasil analisis kinerja simpang dengan MKJI 1997 pada kondisi operasional tahun 2020, 2023, 2025 dan tahun 2028 terdapat pada tabel 5, didapatkan nilai tundaan setiap tahunnya mengalami kenaikan pada setiap simpang. Nilai tundaan (D) mencapai lebih dari $1000 \mathrm{det} / \mathrm{smp}$ bahkan mencapai 2400,09 det/smp terjadi pada Simpang Mangli. Sehingga Simpang Mangli termasuk dalam kategori Los F, kinerja simpang tidak stabil dan volume kendaraan pada simpang melebihi kapasitas. Hal ini disebabkan dampak dari bangunan Tanrise City Jember telah beroperasi.

Hasil analisis kinerja simpang kondisi lima tahun mendatang setelah beroperasi Tnrise City jember yakni tahun 2025, 2028, 2030 dan tahun 2033 dilihat pada tabel 5 . Menunjukkan nilai tundaan meningkat di setiap simpang.
Kinerja simpang yang sangat berpengaruh yakni Simpang Mangli dengan nilai tundaan dibeberapa jam puncak mencapai lebih dari $2000 \mathrm{det} / \mathrm{smp}$. Hal ini menunjukkan bahwa Simpang Mangli termasuk dalam kategori LoS F. Kinerjan simpang buruk dan volume kendaraan melebihi kapsitas.

Gambar 11 S.d 17 menunjukkan hasil kinerja beberapa ruas disekitar Tnarise City Jember pada kondisi eksisting, operasional dan 5 tahun mendatang. Menunjukkan nilai derajat (DS) kejenuhan setiap tahun kondisi mengalami kenaikan di setiap jam puncaknya. Nilai DS terbesar untuk setiap tahunnya terjadi pada ruas Jalan Brawijaya dengan DS $>0,85$ dan mencapai DS $>1$. $\mathrm{Hal}$ ini menunjukkan kinerja ruas $\mathrm{Jl}$. Brawijaya teramasuk dalam kategori $\mathrm{E}$ dan F bahwa kinerja ruas tidak stabil, volume melebihi kapasitas, terjadi akibat adanya pembangunan Tanrise City Jember.

\section{KESIMPULAN}

Berdasarkan hasil dan pembahasan tentang kinerja lalu lintas disekitar akibat pembangunan Tanrise City Jember dengan 
metode MKJI 1997 dapat diambil kesimpulan sebagai berikut:

1. Kinerja simpang pada kondisi eksisting, operasional, 5 tahun mendatang mengalami penurunan. Kinerja Simpang terburuk terjadi di Simpang Mangli. Nilai tundaan (D) > $1000 \mathrm{det} / \mathrm{smp}$ pada jam puncak pagi. Kategori LoS $F$ dengan arus tidak stabil.

2. Kinerja beberapa ruas pada kondisi eksisiting adalah arus stabil. Kinerja terburuk terjadi di Jl. Brawijaya DS > 0,85 yang termasuk dalam kategori $\mathrm{E}$, arus tidak stabil dan volume lalu lintas mendekati atau berada pada kapasiatasnya.

3. Kinerja beberapa ruas pada kondisi operasional dan 5 tahun mendatang mengalami penurunan pada setiap jam puncak. Kinerja terburuk terjadi di Ruas Jl. Brawijaya pada jam puncak 06.30 7.30 dengan nilai $\mathrm{DS}>1$. Kategori $\mathrm{F}$ dengan arus tidak stabil dan volume kendaraan melebihi kapasitas.

\section{DAFTAR PUSTAKA}

[1] Wahyuni, Elis., Sukmawati, S. dan Kriswardhana, W. 2016. Manajemen Rekayasa Lalu Lintas Akibat Pengoperasian Bandar Udara Notohadinegoro Jember. Prosiding FSTPT, Simposium Internasional FSTPT ke 19 di Universitas Islam Indonesia 6: 1314-1322.

[2] N. N. Hayati, S. Sulistyono, D. J. Koesoemawati, and F. T. Kuncoro. 2016. Simulasi Dampak Lalu Lintas Pengoperasian Jember Sport Garden menggunakan PTV. Vistro. Proc. 19th Int. Symp. FSTPT, vol. 8, no. 6, pp. 1196-1205.

[3] Faturrahman. Machsus, 2017. Analisis Dampak Lalu Lintas Akibat
Pembangunan Kantor

Telekomunikasi Manyar Ketoadi 1

Surabaya. Prossiding Seminar Nasional Aplikasi Teknoligi Prasarana Wilayah X $(A T P W) .5$ Agustus 2017. ISNN 2301 - 6752: 215 - 219 .

[4] Rahayu, H., Wiajaya, Misi $\mathrm{H}$ dan dkk. 2013. Analisis Dampak Lalu Lintas Akibat Pembangunan Apartemen Bale Hinggil. J. Tek. Sipil., vol. 2, p. 182.

[5] L. Sariaman dan J. Harianto. 2014. Analisis Kinerja Simpang Bersinyal (Jalan K.H Wahid Hasyim - Jalan Gajah Mada). J. Tek. sipil Usu, vol. 3, No. 2, pp. 1-11.

[6] CIM Pemayu, IG. Purbanto dan N. K. Mataram 2015. Analisis Kinerja Ruas Jalan Diponegoro akibat Bangkitan Perjalanan SDN 5 Pedungan. J. Ilmiah Elektronika Infrastruktur Teknik Sipil

[7] Eka L, Rizq Seundhar P, Deasrilisan Yulipriyono, Eko Kusuma, Amelia. 2017. Perbandingan Hasil Analisis Kinerja Operasional Simpang Bersinyal dengan MKJI 1997 terhadap Hasil Pengamatan Langsung (Simpang Sukun dan Simpang Java Mall Kota Semarang). Jurnal Karya Teknik Sipil. vol.6, pp. 246-262

[8] Anonim, 1997. Manual Kapasitas Jalan Indonesia (MKJI) 1997. Direktorat Jendral Bina Marga, departemen Pekerjaan Umum, Jakarta.

[9] Tamin, Ofyar, Z. 2000. Perencanaan dan Pemodelan Transportasi (Edisi 2). Bandung: Indonesia: Penerbit ITB

[10] Michael G. McNally. 2000. The Four Step model. University of California, Paper UCI-ITS-AS-WP-00-5, Irvine, USA. 